\title{
THE SERUM CHOLESTEROL AND OTHER LIPIDS AFTER ADMINISTRATION OF SITOSTEROL
}

\author{
BY \\ J. M. BARBER AND A. P. GRANT \\ From the Ards and Bangor Hospitals and City Hospital, Belfast \\ Received December 6, 1954
}

The role of cholesterol in the pathogenesis of atherosclerosis has been the subject of much investigation in recent years. The present position has been extensively reviewed by Page (1954) and Katz and Stamler (1953). In coronary artery disease a significant elevation of the plasma cholesterol and of the plasma-cholesterol/phospholipid ratio has been noted (Oliver and Boyd, 1953). The incidence of atherosclerosis has been found to be increased in countries where the diet contains a high total of fats and excessive calories (Keys, 1952). High dietary fat facilitates cholesterol absorption and vice versa (Kim and Ivy, 1952; Melinkoff et al., 1950), but rigid exclusion of the fat from the diet is difficult and unacceptable to the patient. Search for other methods of reducing the blood lipids has proceeded and plant phytosterols have been reported as reducing the serum total cholesterol and changing the other serum lipids.

Sitosterol, a plant sterol, has been shown to reduce experimental hyper-cholesterolæmia in animals and birds (Pollack, 1953; Peterson, 1951). This substance is chemically related to cholesterol from which it differs by an added ethyl group in the side chain. The purpose of this study was to observe the effect of sitosterol on the serum cholesterol and other lipids in patients who suffered from coronary artery disease.

\section{METHOD}

The 26 subjects were a consecutive series in two medical units who had coronary artery disease and an initial serum cholesterol value of $230 \mathrm{mg}$. per $100 \mathrm{ml}$. or more. There was electrocardiographic confirmation of ischæmia or infarction in every case. Almost 100 per cent pure beta-sitosterol was administered orally with an unrestricted diet. This substance is a chalky gritty material insoluble in water. A palatable biscuit containing $1.5 \mathrm{~g}$. was employed. Dosage of $3 \mathrm{~g}$. immediately before the three main meals $(9 \mathrm{~g}$. daily) was continued for periods up to 21 weeks. No side effects were observed. Weekly or fortnightly estimations of the serum total cholesterol, lipid phosphorus, total lipids, and neutral fats were performed during the time of observation.

Neutral fats were calculated from the formula:

Neutral fats $=$ Total lipids $-[(1.5 \times$ total cholesterol $)+(25 \times$ lipid phosphorus $)]$

The age and sex distribution is shown in Table $\mathrm{I}$.

\section{RESULTS}

The results of the biochemical estimations are considered under the sections below.

Serum Total Cholesterol. The mean initial level was higher in the 8 women, 326 as compared to $294 \mathrm{mg}$. per $100 \mathrm{ml}$. in the 18 men (Table I). Two men showed no reduction in any reading with sitosterol. Considerable fluctuations were met with although all tests were made in mid-morning. In 
TABLE I

Initial Serum Total Cholesterol Compared with Mean and Minimum Levels on Sitosterol Regime

\begin{tabular}{|c|c|c|c|c|c|c|c|c|c|c|c|}
\hline \multirow{2}{*}{ Subject } & \multirow{2}{*}{ Sex } & \multirow{2}{*}{ Age } & \multirow{2}{*}{$\begin{array}{c}\text { Initial } \\
\text { T.C. }\end{array}$} & \multicolumn{2}{|c|}{ Therapy T.C. } & \multirow{2}{*}{ Subject } & \multirow{2}{*}{ Sex } & \multirow{2}{*}{ Age } & \multirow{2}{*}{$\begin{array}{c}\text { Initial } \\
\text { T.C. }\end{array}$} & \multicolumn{2}{|c|}{ Therapy T.C. } \\
\hline & & & & Mean & Minimum & & & & & Mean & Minimum \\
\hline $\begin{array}{l}\text { A1 } \\
\text { A2 } \\
\text { A3 } \\
\text { A4 } \\
\text { A6 } \\
\text { A7 } \\
\text { A11 } \\
\text { A14 } \\
\text { A15 } \\
\text { A16 } \\
\text { A18 } \\
\text { A19 } \\
\text { B1 }\end{array}$ & $\begin{array}{l}\mathbf{M} \\
\mathbf{M} \\
\mathbf{M} \\
\mathbf{M} \\
\mathbf{M} \\
\mathbf{M} \\
\mathbf{M} \\
\mathbf{M} \\
\mathbf{M} \\
\mathbf{M} \\
\mathbf{M} \\
\mathbf{M} \\
\mathbf{M}\end{array}$ & $\begin{array}{l}71 \\
66 \\
63 \\
58 \\
71 \\
62 \\
82 \\
61 \\
58 \\
59 \\
63 \\
84 \\
56\end{array}$ & $\begin{array}{l}260 \\
235 \\
230 \\
415 \\
330 \\
320 \\
300 \\
305 \\
305 \\
265 \\
310 \\
280 \\
330\end{array}$ & $\begin{array}{l}245 \\
261 \\
380 \\
361 \\
209 \\
274 \\
392 \\
316 \\
232 \\
235 \\
235 \\
236 \\
268\end{array}$ & $\begin{array}{l}135 \\
150 \\
275^{*} \\
210 \\
120 \\
258 \\
395^{*} \\
175 \\
120 \\
235 \\
235 \\
165 \\
240\end{array}$ & $\begin{array}{l}\text { B2 } \\
\text { B6 } \\
\text { B8 } \\
\text { B10 } \\
\text { B15 } \\
\text { A5 } \\
\text { A12 } \\
\text { A13 } \\
\text { B3 } \\
\text { B4 } \\
\text { B5 } \\
\text { B7 } \\
\text { B9 }\end{array}$ & $\begin{array}{l}\mathbf{M} \\
\mathbf{M} \\
\mathbf{M} \\
\mathbf{M} \\
\mathbf{M} \\
\mathbf{F} \\
\mathbf{F} \\
\mathbf{F} \\
\mathbf{F} \\
\mathbf{F} \\
\mathbf{F} \\
\mathbf{F} \\
\mathbf{F}\end{array}$ & $\begin{array}{l}63 \\
58 \\
52 \\
47 \\
46 \\
50 \\
56 \\
57 \\
55 \\
56 \\
55 \\
53 \\
52\end{array}$ & $\begin{array}{l}265 \\
280 \\
245 \\
365 \\
255 \\
300 \\
258 \\
410 \\
300 \\
360 \\
350 \\
330 \\
300\end{array}$ & $\begin{array}{l}310 \\
302 \\
227 \\
283 \\
222 \\
300 \\
293 \\
331 \\
278 \\
309 \\
256 \\
348 \\
277\end{array}$ & $\begin{array}{l}240 \\
185 \\
190 \\
215 \\
195 \\
245 \\
170 \\
230 \\
215 \\
270 \\
195 \\
315 \\
240\end{array}$ \\
\hline
\end{tabular}

T.C. $=$ Total serum cholesterol. $\quad *$ Minimum above initial value.

24 cases there was a reduction in the minimum level found under the regime and in 17 the mean level was lowered. Estimation of the means of the series showed a fall from 303 to $283 \mathrm{mg}$. per $100 \mathrm{ml}$; this calculation was, of course, influenced by the high levels met with in the two patients mentioned above. The greatest fan in the total cholesterol was not always seen at the start of therapy and only occurred in the first two weeks in 11 of the 26 subjects.

Serum Lipid Phosphorus. The mean levels in both the sexes were $11.0 \mathrm{mg}$. per $100 \mathrm{ml}$. in the men and $11.9 \mathrm{mg}$. per $100 \mathrm{ml}$. in the women before therapy. A fall was found in the treatment period from an initial mean value of $11.3 \mathrm{mg}$. to $10.4 \mathrm{mg}$. per $100 \mathrm{ml}$. over the series (Table II). However, raised and lowered means were fairly evenly distributed, 12 being raised and 14 lowered.

Total Cholesterol-Lipid Phosphorus Ratio. No definite change was found on this value either before or during administration of sitosterol.

Neutral Fats. Raised mean levels were found in 24 out of the 26 patients. In the two subjects with a lower level during the test period, high initial readings were encountered, and both were females. One had a mean fall and the other a rise in the total cholesterol under sitosterol. A marked difference was encountered in the values before treatment, the mean value in women being $176 \mathrm{mg}$. as compared with $68.6 \mathrm{mg}$. per $100 \mathrm{ml}$. in men.

Total Lipids. During sitosterol administration there was a rise which was statistically significant, mean values of $822.3 \mathrm{mg}$. before and $913.8 \mathrm{mg}$. per $100 \mathrm{ml}$. during sitosterol therapy being obtained from the series.

TABLE II

ANALysis of Serum Lipid LeVels obtained before and during Sitosterol Therapy

\begin{tabular}{|c|c|c|c|c|c|c|c|}
\hline & & \multicolumn{2}{|c|}{ Initial } & \multicolumn{2}{|c|}{ During therapy } & \multirow{2}{*}{$\begin{array}{c}\text { Ratio } \\
\text { Difference of } \\
\text { means to } \\
\text { standard error } \\
\text { of the } \\
\text { difference }\end{array}$} & \multirow[b]{2}{*}{$\begin{array}{l}\text { No. of } \\
\text { cases }\end{array}$} \\
\hline & & $\begin{array}{l}\text { Mean } \\
\text { (mg. \%) }\end{array}$ & $\begin{array}{l}\text { Standard } \\
\text { deviation } \\
\text { (mg. \%) }\end{array}$ & $\underset{\text { (mg. \%) }}{\text { Mean }}$ & $\begin{array}{c}\text { Standard } \\
\text { deviation } \\
\text { (mg. \%) }\end{array}$ & & \\
\hline $\begin{array}{l}\text { Total cholesterol } \\
\text { Lipid phosphorus } \\
\text { Neutral fats } \\
\text { Total lipids } \quad \because \\
\text { Total cholesterol/lipid } \\
\text { phosphorus ratio }\end{array}$ & $\begin{array}{ll}. & . \\
. & . \\
. & . \\
. & . \\
& .\end{array}$ & $\begin{array}{r}304 \cdot 0 \\
11 \cdot 3 \\
101 \cdot 7 \\
822 \cdot 3 \\
26.9\end{array}$ & $\begin{array}{r}48 \cdot 7 \\
1 \cdot 4 \\
28 \cdot 8 \\
163 \cdot 1 \\
4 \cdot 6\end{array}$ & $\begin{array}{r}283 \cdot 8 \\
10 \cdot 5 \\
221 \cdot 6 \\
913 \cdot 8 \\
27 \cdot 3\end{array}$ & $\begin{array}{r}49 \cdot 8 \\
2.0 \\
81 \cdot 7 \\
151 \cdot 5 \\
4 \cdot 1\end{array}$ & $\begin{array}{l}1.48 \\
1.72 \\
7.0 \\
2.0 \\
\text { Nil }\end{array}$ & $\begin{array}{l}26 \\
26 \\
26 \\
26 \\
26\end{array}$ \\
\hline
\end{tabular}




\section{Discussion}

Sitosterol produced a fall in the serum cholesterol in the series reported in this paper. The results were suggestive rather than significant, and not as great as might have been expected from the reports of Pollack (1953) and Best et al. (1954a).

The minimum serum cholesterol values during the therapy period were reduced in 24 out of the 26 patients. Pollack showed a fall in this level in 25 out of 26 normal subjects using crude 70 per cent sitosterol from soya bean. The result in the present series might therefore be considered comparable. It was found that considerable fluctuations occurred in most cases, and the present series were analysed on the mean levels obtained during therapy as being a stricter gauge. Under these criteria a fall was only obtained in 17 out of 26 patients, and evaluation of the means of the total sample showed a fall from $303.9 \mathrm{mg}$. to $283.8 \mathrm{mg}$. per $100 \mathrm{ml}$. Best and his co-workers reported on a series of nine patients and found a significant fall in all except one with no escape above the control values.

The diet in this group of patients was unrestricted. This was also so in the two groups discussed above. It is probable that a higher fat content was taken by the American subjects. The dose of sitosterol is probably of great importance and may be the explanation of the poorer results obtained. In this series, $9 \mathrm{~g}$. was given daily, which is equivalent to Pollack's dosage. Since our trial commenced, Best et al. published their results using 15-18g., and Joyner and Kuo (1954) found a significant reduction in the serum cholesterol with 12-24 g. and correlated the degree of decrease with the dosage. They considered doses under $10 \mathrm{~g}$. daily to be without effect, although the present series suggests that there is a change, although small.

We have been unable to demonstrate the fall in total lipids and neutral fat reported by other workers (Best et al., 1954b). In fact our series shows a rise in calculated neutral fat mainly due to an increase in total lipids. One patient (Case B.15) showed a consistent reduction of serum cholesterol when taking sitosterol but nevertheless died of a further myocardial infarction.

\section{Summary AND CONCLUSIONS}

Beta-sitosterol in dosage of $9 \mathrm{~g}$. daily divided between the three main meals produced a fall in the mean serum total cholesterol which was suggestive, though not significant. It is probable that the dosage required for consistent results is twice this amount.

Biscuits containing this compound were palatable, and no side effects were seen.

One patient who showed a reduced serum cholesterol in response to sitosterol died of a further myocardial infarction.

Since the completion of this paper six more patients have been given $6 \mathrm{~g}$. of sitosterol before meals (18 g. daily). In each instance there has been a rapid and consistent fall in the serum cholesterol.

It is a pleasure to thank the Energen Dietary Service, and their Medical Director, Dr. R. Dixon Firth, for their unfailing co-operation and for the supplies of sitosterol. We are also indebted to Dr. H. F. W. Kirkpatrick of the London Clinic for the laboratory work. Dr. W. H. Moffatt helped us at the City Hospital, Belfast.

\section{REFERENCES}

Best, M. M., Duncan, C. H., van Loon, E. J., and Wathen, J. D. (1954a). Circulation, 10, 202.

Joyner, C, Wathen, J. D., van Loon, E. J., Shipley, R. E. (1954b). Circulation, 10, 590.

Joyner, C. R., and Kuo, P. T. (1954). Circulation, 10, 589.

Katz, L. N., and Stamler, J. (1953). Experimental Atherosclerosis. C. C. Thomas, Springfield, Ill.

Keys, A. (1952). Voeding, 11, 539.

Kim, K. S., and Ivy, A. C. (1952). Amer. J. Physiol., 171, 302.

Melinkoff, S. M., Machella, T. E., and Reinhold, J. G. (1950). Amer. J. med. Sci., $220,203$.

Page, I. S. (1954). Circulation, 10, 1.

Peterson, D. W. (1951). Proc. Soc. Exper. Biol. and Med., 78, 143.

Pollack, O. J. (1953). Circulation, 7, 696.

- (1953). Circulation, 7, 702. 